\title{
TEKANAN DARAH PASIEN STROKE YANG MENDAPAT LATIHAN RANGE OF MOTION (ROM) DI RUANG BOUGENVILE RSD MARDI WALUYO BLITAR
}

\section{(Blood Pressure Post Range of Motion (ROM) Stroke Patients At Bougenville Room Mardi Waluyo Blitar Hospital )}

\author{
Aldonna Mariana \\ Program Studi DIII Keperawatan Blitar Jurusan Keperawatan \\ Politeknik Kesehatan Kementerian Kesehatan Malang \\ Email : aldonna_mariana@yahoo.co.id
}

\begin{abstract}
Range Of Motion (ROM) is an action that can be perfomed on stroke patients to prevent muscle and joint stiffness. The purpose of this study was to describe blood pressure in stroke patients who received exercise Range Of Motion (ROM) in the RSD Mardi Waluyo Blitar. Method: Research design was descriptive design. The population in this study is that stroke patients treated in Bougenvile RSD Mardi Waluyo Blitar in 2013 as many as 590 and the average monthly total of 49 stroke patients. Research sample was 33 patients. Its choosed by using purposive sampling technique. Data collection is done by measuring blood pressure and exercise to train Range Of Motion (ROM). Time data collection was done on April $1^{\text {st }}$ until $26^{\text {th }}$, 2014. Result: The results showed that blood pressure in stroke patients after getting a training Range Of Motion (ROM) 39.4\% (13 respondents) had increased, 30.3\% (10 respondents) had decreased and consistent after getting a training Range Of Motion (ROM). Discussion: Recommendations from this study are expected to be more vigilant in monitoring stroke patients trained Range Of Motion (ROM).
\end{abstract}

Keywords: Stroke, Blood Pressure, Range Of Motion (ROM).

\section{PENDAHULUAN}

Stroke telah menjadi masalah kesehatan yang mendunia dan semakin penting, dengan dua pertiga stroke sekarang terjadi di negaranegara yang sedang berkembang. Secara global, pada saat tertentu sekitar 80 juta orang menderita akibat stroke. Menurut WHO setiap tahun, diperkirakan 15 juta orang tersebar di seluruh dunia menderita stroke, dimana kurang lebih 5 juta orang meninggal dan 5 juta orang mengalami cacat permanen (Suryani, 2008 dalam Sikawin, 2013).

Menurut riset kesehatan daerah Departemen Kesehatan Republik Indonesia tahun 2011, didapatkan bahwa di Indonesia, setiap 1000 orang, 8 orang diantaranya terkena stroke. Stroke merupakan penyebab utama kematian pada semua umur, dengan proporsi $15,4 \%$. Setiap 7 orang yang meninggal di Indonesia, 1 diantaranya karena stroke (Depkes RI, 2011 dalam Sikawin, 2013). Gejala sisa pada stroke mencakup komplikasi diantaranya $80 \%$ pasien stroke mengalami penurunan parsial atau total gerakan dan kekuatan lengan atau tungkai di salah satu sisi tubuh di mana kelumpuhan merupakan komplikasi terbesar. Pemulihan atau perawatan stroke merupakan suatu proses yang dapat dilakukan selama di rumah sakit, layanan rehabilitasi, rumah, dan perawatan residensial. Untuk mencegah kecacatan, kita harus memberikan latihan-latihan pasif dan aktif anggota gerak atas dan bawah Range Of Motion (ROM) pasif - aktif yang berguna untuk mencegah terjadinya kekakuan otot dan sendi (Mulyatsih, 2000:6-10).

Sebagian stroke bersifat fatal, sementara yang lain menyebabkan cacat tetap atau sementara. Resiko kematian pada bulan pertama setelah stroke berbeda-beda tergantung pada jenis stroke. Resiko tersebut sekitar $20 \%$ untuk sroke iskemik, $40-70 \%$ untuk perdarahan intraserebrum, dan sekitar $40 \%$ untuk perdarahan subaraknoid. Dampak atau akibat lain setelah stroke adalah sel-sel otak yang mati atau hematom yang terbentuk akan diserap kembali (reabsorbsi) secara bertahap. Setelah stroke iskemik atau perdarahan intraserebrum, sel yang mati dan hematom itu diganti oleh kista yang mengandung cairan serebrospinalis, yaitu cairan yang membasuh otak dan korda spinalis. 
Pada kebanyakan kasus, proses alami ini selesai dalam waktu tiga bulan. Pada saat itu sepertiga dari orang yang selamat akan menjadi tergantung dan mungkin mengalami komplikasi yang dapat menyebabkan kematian atau cacat (Valery, 2006:95-100).

Gejala sisa pada stroke mencakup komplikasi diantaranya $80 \%$ pasien stroke mengalami penurunan parsial atau total gerakan dan kekuatan lengan atau tungkai di salah satu sisi tubuh (kelumpuhan parsial disebut paresis, kelumpuhan total disebut paralisis). Selain itu $30 \%$ mengalami masalah komunikasi atau tidak mampu berbicara, selanjutnya $30 \%$ mengalami kesulitan menelan (disfagia), 10\% mengalami masalah melihat benda-benda di satu sisi (hemianopia) $10 \%$ lagi mengalami penglihatan ganda (diplopia). Kurang dari 10\% mengalami gangguan koordinasi saat duduk, berdiri atau berjalan, 30\% mengalami orientasi kiri kanan bahkan tidak menyadari masalahnya. Hingga $70 \%$ mengalami gangguan suasana hati, 20\% merasakan nyeri bahu. Kurang dari $10 \%$ mengalami kejang atau epilepsi, bahkan menderita sakit kepala (Valery, 2006:100-101).

Dari komplikasi tersebut sekitar $80 \%$ pasien stroke mengalami kelumpuhan di mana kelumpuhan merupakan komplikasi terbesar. Pemulihan atau perawatan stroke merupakan suatu proses yang dapat dilakukan selama di rumah sakit, layanan rehabilitasi, rumah, dan perawatan residensial. Pada fase akut (biasanya 48-72 jam pertama setelah serangan stroke) keadaan belum stabil, sehingga pasien harus berbaring di tempat tidur. Walaupun seperti itu setelah fase akut sikap dan posisi pasien harus diperhatikan, terutama anggota badan yang lumpuh. Selain untuk mencegah kecacatan juga untuk memberikan rasa nyaman kepada pasien. Selain memperhatikan sikap dan posisi pasien, kita juga harus memberikan latihan-latihan pasif dan aktif anggota gerak atas dan bawah Range Of Motion (ROM) pasif - aktif yang berguna untuk mencegah terjadinya kekakuan otot dan sendi. Range Of Motion ROM meliputi gerakan fleksi dan ekstensi antara lain menekuk dan meluruskan sendi bahu, menekuk dan meluruskan siku, memutar pergelangan tangan, menekuk dan meluruskan pergelangan tangan, memutar ibu jari, menekuk dan meluruskan jarijari tangan, menekuk dan meluruskan pangkal paha, menekuk dan meluruskan lutut, gerakan kaki menjauh, gerakan memutar pergelangan kaki (Mulyatsih, 2000:6-10).
Semua gerakan Range Of Motion ROM sangat sulit dilakukan oleh pasien stroke karena kelemahan anggota gerak pada lengan, tungkai, dan bahu sehingga pada $20 \%$ pasien stroke mengalami nyeri pada bahu yang dapat mempengaruhi psikososial stres emosional, cemas yang mendadak atau shock dan ini dapat meningkatkan tekanan darah dan merupakan faktor resiko stroke (Valery, 2006:40 dan 101). Selain itu tekanan darah tinggi (termasuk penderita stroke), jika melakukan latihan olahraga atau aktifitas fisik yang keras akan mendorong tekanan darahnya naik sampai tingkatan yang membahayakan. Itu akan demikian jika pada penderita stroke melakukan aktifitas keras yang akan mengalami resiko besar akan terjadinya stroke hemoragik (Gordon, 2002:108).

Berdasarkan studi pendahuluan pada tanggal 1-8 Januari 2013 di ruang Bougenvile RSD Mardi Waluyo Blitar, terdapat data jumlah pasien stroke pada tahun 2013 sebanyak 590 pasien dengan rata-rata perbulan sekitar 49 pasien stroke. Studi pendahuluan juga mendapatkan bahwa dari 5 pasien stroke di ruang Bougenvile RSD Mardi Waluyo Blitar yang mendapat latihan Range Of Motion (ROM), 3 diantaranya mengalami peningkatan dan 2 diantaranya mengalami penurunan tekanan darah.

Rumusan masalah dalam penelitian ini adalah: Bagaimanakah tekanan darah pasien stroke yang mendapat latihan Range Of Motion (ROM)" di ruang Bougenvile RSD Mardi Waluyo Blitar.

Tujuan umum dalam penelitian ini adalah untuk mengetahui tekanan darah pada pasien stroke yang mendapat latihan Range Of Motion (ROM) di RSD Mardi Waluyo Blitar.

Manfaat penelitian ini bagi peneliti sebagai dasar untuk mengembangkan diri di masa yang akan datang dan mendapatkan informasi yang berharga tentang gambaran tekanan darah pasien stroke yang mendapat latihan Range Of Motion (ROM), bagi institusi keperawatan sebagai sumbangan pemikiran dan acuan bagi ilmu pengetahuan tentang gambaran tekanan darah pasien stroke yang mendapat latihan Range Of Motion (ROM), bagi Rumah Sakit Mardi Waluyo Blitar hasil penelitian ini akan berguna bagi ruang Bougenvile RSD Mardi Waluyo Kota Blitar sebagai data yang akurat guna mengambil kebijakan dalam upaya meningkatkan mobilisasi pada pasien stroke 
yang mendapat latihan Range Of Motion (ROM).

\section{BAHAN DAN METODE}

Desain dalam penelitian ini adalah penelitian deskriptif. Populasi dalam penelitian ini adalah pasien stroke yang dirawat di ruang Bougenvile RSD Mardi Waluyo Blitar pada tahun 2013 sebanyak 590 dan rata-rata perbulan sebanyak 49 pasien stroke dengan besar sampel yang diambil adalah sebanyak 33 responden menggunakan teknik purposive sampling. Penelitian dilakukan di ruang Bougenvile RSD. Mardi Waluyo Blitar pada tanggal 1-26 April
2014. Kriteria inklusi penelitian ini adalah pasien stroke yang melewati fase akut (biasanya 48-72 jam pertama setelah serangan stroke), pasien stroke yang tidak mengalami koma, dan pasien stroke yang tidak terpasang alat bantu pernafasan. Dalam penelitian ini instrumen yang digunakan adalah tensimeter digital.

Data yang dikumpulkan dari hasil yang telah diisi oleh responden kemudian diolah melalui tahap editing, koding, selanjutnya data disajikan dalam bentuk diagram dan tabel frekuensi. Analisis data yang digunakan adalah deskriptif.

\section{HASIL PENELITIAN} stroke.

Berikut ini disajikan data umum hasil penelitian yang meliputi umus, jenis kelamin dan lama

Tabel 1 Data umum pasien stroke di Ruang Bougenville RSD. Mardi Waluyo Blitar, April 2014.

\begin{tabular}{|c|c|c|c|}
\hline No & Karakteristik & $\mathbf{f}$ & $\%$ \\
\hline \multirow[t]{6}{*}{1} & Usia Pasien Stroke & & \\
\hline & $-41-50$ tahun & 8 & 24,2 \\
\hline & $-51-60$ tahun & 8 & 24,2 \\
\hline & $-61-70$ tahun & 10 & 30,3 \\
\hline & $-71-80$ tahun & 6 & 18,2 \\
\hline & $-81-90$ tahun & 1 & 3 \\
\hline \multirow[t]{3}{*}{2} & Jenis Kelamin & & \\
\hline & - Laki - laki & 12 & 36 \\
\hline & - Perempuan & 21 & 64 \\
\hline \multirow[t]{3}{*}{3} & Lama Stroke & & \\
\hline & $-4-6$ hari & 25 & 76 \\
\hline & $-7-9$ hari & 8 & 24 \\
\hline \multirow[t]{4}{*}{4} & $\begin{array}{l}\text { Tekanan darah pasien stroke setelah } \\
\text { dilakukan ROM }\end{array}$ & & \\
\hline & - Meningkat & 13 & 39,4 \\
\hline & - Tetap & 10 & 30,3 \\
\hline & - Menurun & 10 & 30,3 \\
\hline
\end{tabular}

Tabel 2 Hasil tabulasi silang antara perubahan tekanan darah setelah dilatih Range Of Motion (ROM) dengan usia responden di RSD. Mardi Waluyo Blitar, April 2014.

\begin{tabular}{lcccccccc}
\hline USIA & \multicolumn{9}{c}{ Tekanan darah } \\
& \multicolumn{2}{c}{ Meningkat } & \multicolumn{2}{c}{ Tetap } & \multicolumn{2}{c}{ Menurun } & \multicolumn{2}{c}{ Total } \\
\cline { 2 - 12 } & $\mathrm{n}$ & $\%$ & $\mathrm{n}$ & $\%$ & $\mathrm{n}$ & $\%$ & $\mathrm{n}$ & $\%$ \\
\hline $41-50$ th & 2 & 6,1 & 3 & 9,1 & 3 & 9,1 & 8 & 24,2 \\
$51-60$ th & 4 & 12.1 & 1 & 3.0 & 3 & 9.1 & 8 & 24.2 \\
$61-70$ th & 5 & 15.2 & 3 & 9.1 & 2 & 6.1 & 10 & 30.3 \\
$71-80$ th & 2 & 6.1 & 2 & 6.1 & 2 & 6.1 & 6 & 18.2 \\
$81-90$ th & 0 & .0 & 1 & 3 & 0 & .0 & 1 & 3 \\
\hline
\end{tabular}


Tabel 3 Hasil tabulasi silang antara perubahan tekanan darah setelah dilatih Range Of Motion (ROM) dengan jenis kelamin responden di RSD. Mardi Waluyo Blitar, April 2014 $(\mathbf{n}=33)$.

\begin{tabular}{lcccccccc}
\hline Jenis Kelamin & \multicolumn{8}{c}{ Tekanan darah } \\
\cline { 2 - 11 } & \multicolumn{2}{l}{ Meningkat } & \multicolumn{2}{c}{ Tetap } & \multicolumn{2}{c}{ Menurun } & \multicolumn{2}{c}{ Total } \\
\cline { 2 - 11 } Laki-laki & $\mathrm{n}$ & $\%$ & $\mathrm{n}$ & $\%$ & $\mathrm{n}$ & $\%$ & $\mathrm{n}$ & $\%$ \\
\cline { 2 - 11 } Perempuan & 6 & 18,2 & 1 & 3 & 5 & 15,2 & 12 & 36,4 \\
\hline
\end{tabular}

Tabel 4 Hasil tabulasi silang antara perubahan tekanan darah setelah dilatih Range Of Motion (ROM) dengan lama stroke responden di RSD. Mardi Waluyo Blitar, April 2014 $(\mathbf{n}=33)$.

\begin{tabular}{lcccccccc}
\hline Lama stroke & \multicolumn{7}{c}{ Tekanan darah } \\
\hline & Meningkat & \multicolumn{1}{c}{ Tetap } & Menurun & Total \\
\cline { 2 - 10 } & $\mathrm{n}$ & $\%$ & $\mathrm{n}$ & $\%$ & $\mathrm{n}$ & $\%$ & $\mathrm{~N}$ & $\%$ \\
\cline { 2 - 10 } 4-6 hari & 8 & 24,2 & 10 & 30,3 & 7 & 21,2 & 25 & 75,8 \\
7-9 hari & 5 & 15,2 & 0 & 0 & 3 & 9,1 & 8 & 24,2 \\
\hline
\end{tabular}

\section{PEMBAHASAN}

Berdasarkan data umum hasil penelitian yang dilakukan terhadap 33 responden di ruang Bougenvile didapatkan data bahwa pasien stroke terbanyak berusia 61-70 tahun yaitu sebanyak 30,3\% (10 pasien). Menurut Valery (2006:3031) resiko terkena stroke dan tekanan darah tinggi meningkat sejak usia 45 tahun. Setelah mencapai usia 50 tahun, setiap penambahan usia tiga tahun meningkatkan resiko stroke sebesar $11-20 \%$, dengan peningkatan bertambah seiring usia. Orang dengan usia lebih dari 65 tahun memiliki resiko paling tinggi, tetapi hampir $25 \%$ dari semua stroke dan tekanan darah tinggi terjadi pada orang berusia kurang dari ini. Menurut Valery (2006:25) bahwa tekanan darah yang meningkat secara perlahan merusak dinding pembuluh darah dengan memperkeras arteri dan mendorong terbentuknya bekuan darah dan aneurisme, yang semua mengarah pada stroke terutama pada orang berusia diatas 45 tahun. Peneliti berpendapat dalam hal ini bahwa pada usia muda orang cenderung tidak memperhatikan gaya hidupnya seperti merokok (aktif dan pasif), makan yang tidak sehat atau instan, konsumsi alkohol yang berlebihan, tidak banyak aktifitas fisik, serta obesitas, semua itu menyebabkan tekanan darah meningkat secara perlahan sehingga menyebabkan stroke pada usia tua.

Berdasarkan tabel 1 dari 33 responden pasien stroke terbanyak adalah berjenis kelamin perempuan sebanyak 64\% (21 pasien). Menurut Valery (2006:30-31) bahwa laki-laki berusia kurang dari 65 tahun memiliki resiko terkena stroke iskemik atau perdarahan intraserebrum lebih tinggi sekitar $20 \%$ daripada perempuan. Namun wanita usia berapa pun memiliki resiko perdarahan subaraknoid sekitar 50\% lebih besar. Sedangkan menurut Anna Palmer dan William (2007:16) tekanan darah tinggi biasanya timbul akibat penyakit lain seperti penyakit ginjal atau gangguan pada kelenjar adrenal. Stres emosional yang mendadak atau shock, baik positif maupun negatif, jika berkombinasi dengan faktor resiko lain (misalnya aterosklerosis berat, penyakit jantung, atau hipertensi) juga dapat memicu stroke (Valery, 2006:40). Peneliti berpendapat bahwa pada kebanyakan perempuan terutama ibu rumah tangga lebih banyak menghabiskan waktunya dirumah dan jarang melakukan aktivitas fisik, stres psikologis akibat permasalahan dan gaya hidup yang tidak sehat sehingga menyebabkan stroke. Hal ini juga sesuai dengan pendapat Valery (2006:39) bahwa pada wanita yang menjelang menopause yang menggunakan terapi hormon replacement therapy (HRT) terutama kombinasi estrogen dan progesteron dapat meniningkatkan resiko stroke $33 \%$ dan penyakit jantung koroner.

Hasil secara umum berdasarkan tabel 1 dari 33 responden setelah dilakukan Range of Motion (ROM), menunjukkan bahwa 39,4\% (13 pasien) mengalami peningkatan tekanan darah, 
sedangkan $30,3 \% \quad$ (10 pasien) mengalami penurunan dan tidak mengalami perubahan tekanan darah setelah dilakukan Range Of Motion (ROM). Hasil ini didapatkan dari 3 indikator yaitu tekanan darah sebelum dilakukan latihan Range Of Motion (ROM), tekanan darah setelah dilakukan Range Of Motion (ROM), dan perubahan tekanan darah sebelum dan sesudah dilakukan Range Of Motion (ROM). Ini sesuai dengan tujuan penelitian yaitu untuk mengetahui tekanan darah pasien stroke setelah dilakukan Range Of Motion (ROM). Menurut Vitahealth (2004:14), menyebutkan bahwa tekanan darah akan cenderung tinggi bersama dengan peningkatan umur, selain itu keadaan pikiran, stres, perasaan takut atau cemas juga cenderung membuat tekanan darah meningkat. Tekanan darah untuk masing-masing individu juga bervariasi dalam sehari. Pada saat seseorang sedang melakukan kegiatan olahraga atau aktivitas yang melelahkan tekanan darahnya akan naik dan ketika tidur akan turun.

Peneliti berpendapat bahwa tekanan darah pada pasien stroke yang dilatih Range Of Motion (ROM) akan meningkat sebab pada pasien stroke anggota tubuhnya mangalami kelemahan dan kelumpuhan ketika dilatih atau digerakkan untuk dilakukan Range Of Motion (ROM) otomatis jantung yang semula berjalan pelan akan memompa darah keseluruh tubuh lebih cepat selain itu gerakan Range Of Motion (ROM) sangat sulit dilakukan oleh pasien stroke karena kelemahan anggota gerak pada lengan, tungkai, dan bahu sehingga pada pasien stroke mengalami nyeri pada bahu yang dapat mempengaruhi psikososial stres emosional, cemas yang mendadak atau shyok dan ini dapat meningkatkan tekanan darah dan apabila ini terjadi pada pasien stroke akan membahayakan kondisinya. Selain itu menurut Vitahealth (2004:37) bahwa tekanan darah yang terlalu tinggi dapat menyebabkan pembuluh darah yang sudah lemah menjadi pecah, bila hal ini terjadi pada pembuluh darah otak maka terjadi perdarahan otak yang berakibat kematian.

Berdasarkan data khusus pada tabel 2 bahwa pasien stroke pada usia 61-70 tahun yang dilakukan Range Of Motion (ROM) tekanan darahnya cenderung mengalami peningkatan sebanyak 30,3\% (10 pasien). Menurut Vitahealth (2004:25) sejalan dengan penambahan usia, tekanan darah seseorang akan meningkat, hal ini dikarenakan faktor kurangnya aktifitas fisik, berat badan berlebih, dan gangguan dari perubahan hormonal. Menurut William
Frishman M.D Profesor bidang Kedokteran dalam Vitahealth (2004:19) bahwa pada saat diam atau tidur (tidak melakukan aktivitas) tekanan darah akan cenderung turun dan ketika melakukan aktivitas atau kegiatan berat maka tekanan darah akan meningkat. Hal ini dikarenakan jantung kita berdenyut lebih cepat, kita bernafas lebih cepat, dan kemudian tekanan darah akan meningkat sewaktu melakukan aktivitas. Peneliti berpendapat bahwa usia diatas 60 tahun cenderung mengalami hipertensi karena penumpukan lemak dari gaya hidupnya sewaktu muda selain itu orang cenderung jarang melakukan aktivitas terutama penderita stroke yang mengalami kelumpuhan akan lebih banyak berdiam diri ditempat tidur, selain itu pada usia tua regulasi baroreseptor dan kemoreseptor sudah tidak optimal sehingga pada waktu dilatih Range Of Motion (ROM) tekanan darah akan meningkat.

Berdasarkan tabel 3 tentang tabulasi silang jenis kelamin dengan perubahan tekanan darah dari 33 responden pasien stroke yang dilakukan Range Of Motion (ROM) pada perempuan lebih cenderung meningkat sebesar 21,2\% (7 orang). Menurut Edward D. Frohlich, M.D. Ketua Badan penelitian Hipertensi di American Heart Association dalam Vitahealth (2004:26) bahwa wanita setelah mengalami menopause berpeluang lebih besar mengalami tekanan darah yang tinggi. Para pakar menduga perubahan hormonal berperan besar dalam terjadinya hipertensi dikalangan wanita. Dalam Vitahealth (2004:28) faktor pekerjaan dan stres juga dapat mempengaruhi tekanan darah karena dalam kondisi tertekan, adrenalin dan kortisol dilepaskan ke aliran darah sehingga menyebabkan peningkatan tekanan darah agar tubuh siap untuk bereaksi. Itulah yang terjadi saat dalam kondisi cemas atau stres yang kebanyakan adalah wanita. Peneliti dalam hal ini berpendapat bahwa dalam kondisi sedang dilatih Range Of Motion (ROM) pada kebanyakan pasien stroke anggota tubuhnya akan cenderung sakit apabila digerakkan dan ini akan menimbulkan kecemasan pada sebagian pasien wanita yang dapat meningkatkan tekanan darahnya meningkat.

Pada tabel 4 tentang tabulasi silang lama stroke dengan perubahan tekanan darah, dari 33 responden pasien stroke mengalami peningkatan setelah dilatih Range Of Motion (ROM) pada 46 hari setelah stroke. Ini disebabkan karena pada rentan serangan awal stroke pada fase akut (biasanya 48-72 jam pertama setelah serangan 
stroke) keadaan belum stabil, sehingga pasien harus berbaring di tempat tidur. Walaupun seperti itu setelah fase akut sikap dan posisi pasien harus diperhatikan, terutama anggota badan yang lumpuh. Selain untuk mencegah kecacatan juga untuk memberikan rasa nyaman kepada pasien (Mulyatsih, 2000:6). Menurut pendapat peneliti pada fase akut tersebut pasien stroke masih mengalami kekakuan otot dan sendi serta kelumpuhan yang masih sulit digerakkan sehingga pada saat dilkukan Range Of Motion (ROM) cenderung mengalami peningkatan karena jantung yang semula memompa normal menjadi cepat karena adanya gerakan.

\section{SIMPULAN DAN SARAN Simpulan}

Berdasarkan penelitian tentang gambaran tekanan darah pada pasien stroke yang mendapat latihan Range Of Motion (ROM) yang telah dilaksanakan pada tanggal 1-26 April 2014 di ruang Bougenvile RSD Mardi Waluyo Kota Blitar, dapat diambil kesimpulan dari 33 responden menunjukkan bahwa 13 responden $(39,4 \%)$ pasien stroke yang dilatih Range of Motion (ROM) mengalami peningkatan tekanan darah, sedangkan 10 responden (30,3\%) mengalami penurunan tekanan darah dan 10 responden $(30,3 \%)$ tidak mengalami perubahan tekanan darah setelah dilakukan Range Of Motion (ROM).

\section{Saran}

Bagi pelayanan kesehatan diharapkan hasil penelitian ini dapat dijadikan sebagai masukan data tentang tekanan darah pasien stroke yang mendapat latihan Range Of Motion (ROM) di ruang Bougenvile RSD Mardi Waluyo Kota Blitar, dan lebih waspada dalam memantau pasien stroke yang dilatih Range Of Motion (ROM), sehingga dapat mengurangi resiko besar akan terjadinya stroke yang membahayakan, bagi peneliti selanjutnya diharapkan hasil penelitian ini dapat dijadikan sebagai data dasar untuk melaksanakan penelitian lebih lanjut yang berkaitan dengan tekanan darah pasien stroke yang mendapat latihan Range Of Motion (ROM) di ruang Bougenvile RSD Mardi Waluyo Kota Blitar.

\section{DAFTAR RUJUKAN}

Batticaca, F. (2008) Asuhan Keperawatan pada Klien dengan Gangguan Sistem Persyarafan. Salemba Medika, Jakarta
Beevers. (2002) Tekanan Darah. PT Dian Rakyat, Jakarta

Gordon, N. F. (2002) Stroke Panduan Latihan Lengkap. PT Raja Grafindo Persada, Jakarta

Hidayat, A. A. A. (2009) Kebutuhan Dasar Manusia. Salemba Medika, Jakarta

Mulyatsih, E. (2003) Stroke. Balai Penerbit FKUI, Jakarta

Palmer, A. \& William, B. (2007) Tekanan Darah Tinggi. Erlangga, Jakarta

Pinzon, R. \& Asanti, L. (2010) Awas Stroke! Pengertian, Gejala, Tindakan, Perawatan, dan Pencegahan. CV Andi Offset, Yogyakarta

Sherwood, L. (2012) Fisiologi Manusia. Buku Kedokteran EGC, Jakarta

Sikawin, C. A., Mulyadi., Palandeng, H. (2013) Pengaruh latihan range of motion (ROM) terhadap kekuatan otot pada pasien stroke di IRNA F Neurologi BLU RSUP Prof. Dr. R.D. Kandou Manado, ejournalKeperawatan (eKp) Volume 1. 2013; 1

Suratun dkk. (2008) Asuhan Keperawatan Klien Gangguan Sistem Muskuloskletal. Buku Kedokteran EGC, Jakarta

Valery, F. (2006) Stroke. PT Bhuana Ilmu Populer, Jakarta

Vitahealth. (2004) Hipertensi. PT Gramedia Pustaka Utama, Jakarta 